American Journal of Pharmaceutical Education 2020; 84 (1) Article 7462.

\title{
COMMENTARY
}

\section{Appropriateness of Term Limits for Administrative Appointments in Pharmacy Programs}

\author{
Daniel R. Malcom, PharmD, ${ }^{\text {a,b }}$ Karen Farris, PhD, ${ }^{c}$ David J. Feola, PharmD, PhD, ${ }^{\mathrm{d}}$ \\ Peter M. Gannett, PhD, ${ }^{\mathrm{e}}$ Anandi V. Law, PhD, ${ }^{\mathrm{f}}$ Katherine S. O’Neal, PharmD, MBA, ${ }^{\mathrm{g}}$ \\ Francine D. Salinitri, PharmD, ${ }^{\mathrm{h}}$ Katherine Tromp, PharmD, ${ }^{\mathrm{i}}$ Annesha White, $\mathrm{PhD}^{\mathrm{j}}$ \\ ${ }^{a}$ Sullivan University College of Pharmacy and Health Sciences, Louisville, Kentucky \\ ${ }^{\mathrm{b}}$ Associate Editor, American Journal of Pharmaceutical Education, Arlington, Virginia \\ ${ }^{\mathrm{c}}$ University of Michigan College of Pharmacy, Ann Arbor, Michigan \\ ${ }^{\mathrm{d}}$ University of Kentucky College of Pharmacy, Lexington, Kentucky \\ ${ }^{\mathrm{e}}$ Nova Southeastern University College of Pharmacy, Fort Lauderdale, Florida \\ ${ }^{\mathrm{f}}$ Western University of Health Sciences College of Pharmacy, Pomona, California \\ ${ }^{g}$ University of Oklahoma Health Sciences Center College of Pharmacy, Oklahoma City, Oklahoma \\ ${ }^{\mathrm{h}}$ Wayne State University, Eugene Applebaum College of Pharmacy and Health Sciences, Detroit, Michigan \\ ${ }^{i}$ Lake Erie College of Osteopathic Medicine School of Pharmacy, Bradenton, Florida \\ ${ }^{\mathrm{j}}$ University of North Texas Health Science Center College of Pharmacy, Fort Worth, Texas
}

Submitted December 6, 2018; accepted June 25, 2019; published January 2020.

\begin{abstract}
The appropriateness of term limits for administrative appointments is a subject of much discussion, not just within pharmacy programs, but in organizations of all types. The prospect of term limits for involves a wide variety of important organizational issues, including succession planning, institutional memory, strategic decision-making, and concepts regarding leadership styles overall. This paper examines both sides of the debate regarding the appropriateness of term limits for administrative appointments. Arguments supporting term limits include the ability for strategic changes in the diversity of leaders as well as a more focused effort on continuous quality improvement. The arguments against term limits focus around the need for stability and the time involved in the development of effective leaders.
\end{abstract}

Keywords: term limits; academia; administration; leadership; succession planning

Term limits for leadership positions have long been a matter of debate, both within and outside academia. The essential question we address here is whether appointed leadership positions in pharmacy programs, such as deans, assistant/associate deans, and department/ division chairs, should have specific term limits for their positions or if the duration of these positions should be unspecified or undefined by the institution. The context for this discussion is centered on the current higher education environment often characterized by significant change and uncertainty. Some organizations are rethinking and reviewing past practices regarding term limits to ensure that they meet current institutional demands and requirements. ${ }^{1}$ Very little data of any type are available about the presence or influence of term limits at

Corresponding Author: Daniel R. Malcom, Sullivan

University College of Pharmacy and Health Sciences, 2100

Gardiner Ln., Louisville, KY 40205. Tel: 502-413-8969.

Email: dmalcom@sullivan.edu. the organizational level in business or government, as well as in academic leadership at the university, college, or department/division level.

No direct evidence exists to support or refute the influence of term limits on academic organizations. The effects of term limits are difficult to study given the lack of a consistent outcome of interest, numerous potential confounders, and the interval from implementation of any changes to their subsequent impact. Service in state legislatures is one of the only venues in which term limits have been studied. Even in that setting, there is little reliable data, with the most comprehensive results generated through surveys. ${ }^{2,3}$ The difference between term limits for elected leaders of democratic forms of government and term limits for appointed or hired administrative positions is critical for this debate, as the former involves a key check (real or perceived) on the power of government, while the latter is more often related to contractual or employment issues and organizational effectiveness. 


\section{American Journal of Pharmaceutical Education 2020; 84 (1) Article 7462.}

This topic of term limits was debated at the 2018 American Association of Colleges of Pharmacy (AACP) Interim Meeting in Long Beach, California, in the session, "Key Issue Debate 2: Administrative Appointments Should Be Term Limited," between a group from the 20172018 Academic Leadership Fellows Program (ALFP) and one composed of ALFP alumni from the 2009-2010 cohort. As noted previously, policies and procedures for term limits vary substantially among institutions. For the purposes of the debate, term limits were defined within the boundary of five to 10 years. Additionally, the concept of reappointment of a leader to specified terms (ie, fixed three-year terms for a department chair with the ability to be reappointed indefinitely) was excluded from the debate, as this approach is more applicable to contractual employment than to intentional defined term limits for leadership positions.

Historically, term limits for administrative appointments have ranged from three to five years, with or without the opportunity to be renewed; however, some smaller community colleges have one- or two-year terms for department/division chairs and/or program deans. ${ }^{4-6}$ Some organizations have rotating terms for department chairs elected from faculty members within the department, with periods of transition built into the terms to allow for mentorship and handoff, while others have no term limits. ${ }^{6,7}$

The current landscape of term limits for administrative positions within academic pharmacy is unknown. In an effort to provide at least some context in preparation for the ALFP debate, an informal, anonymous, voluntary four-item poll was conducted within the AACP Connect system (https://connect.aacp.org) with a convenience sample of pharmacy faculty members and administrators in January 2018. Questions were all free-text and included demographic questions (institution and role), whether term limits were present for leadership positions within their institutions, and (if term limits were present) the length of the terms. Respondents also were asked if they supported term limits and were given a comment box in which to explain their reasoning and to indicate whether their institutions had term limits in place. Thirty-seven people responded to the survey, all representing different institutions. Among those responding were 21 administrators (including department/division chairs, assistant and associate deans, experiential education directors, and deans) and 16 faculty members reporting no formal administrative responsibilities. Eight of the 37 programs represented $(21.6 \%)$ reported having term limits, while 29 $(78.4 \%)$ did not have term limits. Seven of the eight $(87.5 \%)$ with term limits responded that the terms were three to five years in length, and three $(37.5 \%)$ indicated that the terms could be renewed; one $(12.5 \%)$ of the eight programs did not respond to that item. Among the respondents, 21 (56.8\%) indicated that they opposed term limits, while nine $(24.3 \%)$ indicated that they supported term limits. Five respondents (13.5\%) indicated that they both supported and opposed term limits, while two respondents did not reply to that question. Results of the poll were shared with members of the debating groups prior to the debate itself.

As this was an informal online poll with a convenience sample of participants, these results should be interpreted with caution and no substantive conclusions should be made from them. Importantly, no data were collected regarding the ratio of male to female participants, an individual's status as a term-limited administrator (or not), or any type of correlation with formal survey results, such as the AACP Faculty Survey. However, it was evident from the poll results that some pharmacy programs do possess term limits for leadership positions and that a more formal and standardized assessment of the status of term limits for administrative positions in pharmacy programs is needed.

Similarly, only limited data are available regarding the prevalence of term limits in higher education outside of pharmacy. A 2011 cross-sectional survey of 105 college/ university department chairs found that $21 \%$ had termlimited positions, while the majority (77.1\%) had no term limits $\left(1.9 \%\right.$ did not respond to that item). ${ }^{8}$ Additionally, $38.1 \%$ of department chairs reported that they were appointed, while $16.7 \%$ were elected to their positions (the remainder indicated a combination of appointment and election). ${ }^{8}$ A 2016 survey from the Council of Independent Colleges (which includes over 700 member institutions) included responses from 1,083 department or division chairs across the United States. ${ }^{6}$ In this survey, $41 \%$ of respondents reported having no defined terms or term limits. ${ }^{6}$ Additionally, $62 \%$ of respondents to this survey reported that they were appointed to their position by the chief academic officer (CAO) or dean, while $28 \%$ were elected (the remainder responded "other"). While any extrapolation of these survey results is limited, it is evident that a consensus for or against term limits as an organizational structure does not exist currently.

Discussions in higher education editorials and periodicals also have highlighted the issue of term limits. In a 2017 article, Dunn and Halonen ask the question, "Have you stayed too long?" of department chairs and other academic leaders, noting that with leadership positions, time-delimited goals (such as those in a strategic plan or with a term-limited position) can be good career demarcation points. ${ }^{1}$ While Dunn and Halonen do not take a position on the effectiveness of term limits, only noting 


\section{American Journal of Pharmaceutical Education 2020; 84 (1) Article 7462.}

that many colleges and schools have term limits, they do offer advice for anyone in a leadership position on the options that may be available at the end of a term, such as returning to a faculty position or pursuing a higher leadership position. ${ }^{1}$

\section{Arguments Supporting Term Limits}

A key concept that underpins the support for termlimited leadership appointments is the idea of faculty governance. The Accreditation Council for Pharmacy Education (ACPE) Standards 2016 require in Key Element 8.7 that "faculty participat[e] in the governance of the college or school." $"$ Administrative positions are not lifetime appointments, nor are they intended to be. While the day-to-day decision-making within a school or college cannot be a democratic process, a leader should ultimately be accountable to the faculty, and having term-limited appointments is one way to support that accountability. There are four key points that demonstrate that term limits are necessary and vital to the continued growth of an organization.

A 2017 study by Assemi and colleagues noted that the average tenure of a chief executive officer (CEO) pharmacy dean in the United States was 5.7 years, which is down from 7.5 years in $2004 .{ }^{10}$ In addition, over half of department chairs had been in their current position for five or fewer years. In 2016 there were more than 20 CEO dean positions available within schools and colleges of pharmacy. ${ }^{11}$ With this turnover, institutions are dealing with the challenges and costs of a dean search and the need to fill interim positions in more of a reactive vs. a proactive manner. This can be a time-sensitive decision requiring consideration of qualifications, strategic goals of the organization or group, and impact on faculty and staff members. All these factors can lead to disruption in administrative functions. Term limits can allow for a proactive process of predictable change wherein all constituents across the organization are aware. Use of term limits would also be a structural element to ensure that plans for adequate continuity are in place and a check so that all the power and knowledge does reside with a single individual.

The process of "change management" could also lend itself to the development and monitoring of strategic plans. Change management has been described as "the process of continually renewing an organization's direction, structure, and capabilities" to meet the evolving needs of stakeholders. ${ }^{12}$ Undeniably, organizations should have strategic plans and/or a vision of where it plans to be. Therefore, recognizing what needs to take place to manage change to achieve that vision is critical. A key piece to achieving that vision is being able to select the right individual to lead the organization through a strategic plan. Term limits allow for management of change and growth for institutions to help ensure achievement of the longer-term strategic plan and vision.

Succession planning is an issue facing leaders at institutions across the Academy as well as in other areas, including business. ${ }^{13}$ The increase in CEO dean vacancies has been attributed to long-standing deans retiring or moving to new positions. ${ }^{11}$ These circumstances can compromise operations and require an interim dean or chair to immediately step into the role and be expected to have refined leadership skills, which may or may not be the case. This transition could, in turn, open other unplanned vacancies. In 2007, Conklin and colleagues asked pharmacy faculty members to identify five reasons why they left a previous institution. ${ }^{14}$ The number one reason identified was the faculty member was seeking a new challenge or desired a change. Adoption of term limits may provide opportunities for leadership and growth. We posit that if reasonable term limits were in place at these colleges, that succession planning could be intentionally designed and conducted, providing an orderly process to develop appropriate leadership resources to ensure the sustainability of the college. ${ }^{11}$

Instituting term limits as a part of succession planning also provides opportunities to enhance diversity in leadership. Since 1984, more entry-level professional pharmacy degrees (Bachelor of Science [BS] and Doctor of Pharmacy [PharmD]) have been awarded annually to women than men. ${ }^{15}$ In 2017, $61.9 \%$ of PharmD graduates were women, while only $50.3 \%$ of all full-time faculty members were women. ${ }^{15,16}$ Academic pharmacy, however, is not representative of this shift overall. A full breakdown of gender diversity in both faculty and administration from 2009 to 2018 is shown in Table 1.

Leadership positions in pharmacy programs are also not representative of the overall proportion of male and female faculty members, a problem that has been discussed previously in the literature. ${ }^{17}$ Most CEO dean positions in 2017-2018 (the most recent data available) were held by men $(77.9 \%$ men vs $22.2 \%$ women) and a smaller proportion of women held administrative positions, including CEO dean, associate dean, and assistant dean, as well as department chair (58.9\% men vs $41.1 \%$ women). ${ }^{16}$ There is also evidence of higher turnover intentions among women who experience more frequent denial of promotion and tenure. ${ }^{17,18}$ Even with the significant increase in PharmD programs in recent years, the proportion of women holding the CEO dean title has actually dropped since 2009 (24.5\% in 2009-2010 to $22.1 \%$ in 2017-2018). Underrepresentation of women in leadership positions also has been recognized in medical education. ${ }^{19}$ 
American Journal of Pharmaceutical Education 2020; 84 (1) Article 7462.

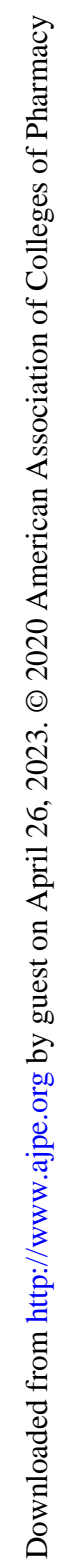

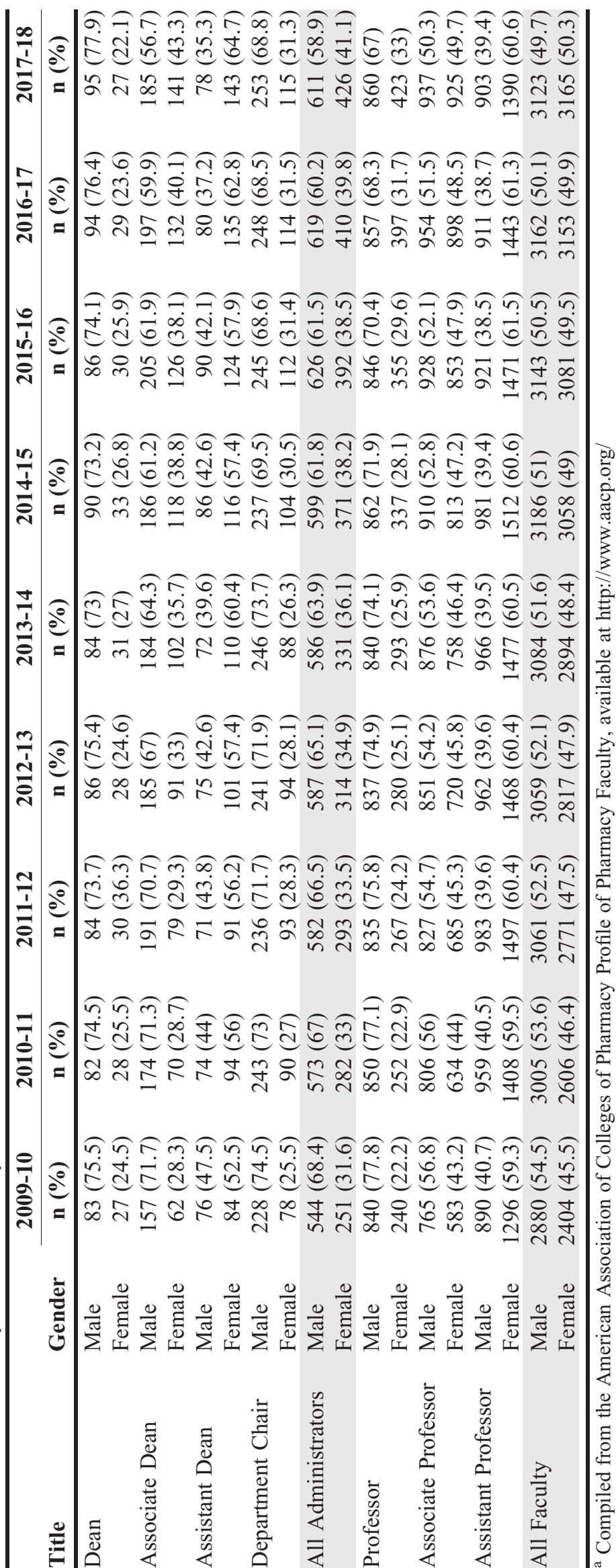




\section{American Journal of Pharmaceutical Education 2020; 84 (1) Article 7462.}

While the overall numbers are out of proportion, there is evidence of progress in working toward gender diversity. The proportion of women at the associate dean level has increased from $28.3 \%$ in $2009-2010$ to $43.3 \%$ in 2017-2018, and the proportion of women in assistant dean positions rose from $52.5 \%$ in $2009-2010$ to $64.7 \%$ in 2017-2018. As a proportion of all administrators, women increased from $31.6 \%$ in $2009-2010$ to $41.1 \%$ in 2017 2018. Given the changing demographics of the pharmacy faculty and administrative workforce, the position of CEO dean appears to be a "glass ceiling" of sorts for women in academic pharmacy. "Lifetime" appointments to academic administrative roles serve as an artificial barrier to the advancement of women in leadership positions. Careful incorporation of term-limited positions as a part of overall strong faculty governance and succession planning would provide opportunities for women to seek higher leadership positions that they may not have been considered for in the past.

Finally, in academic leadership and administration, advancement of knowledge and creating a culture of quality improvement is critical. The mark of a great leader is one who combines "extreme personal humility with intense professional will," putting the organization in front of the individual. ${ }^{20}$ Term limits embody this "organization-first" leadership characteristic. Knowing during the hiring process that term limits are in place informs candidates that the position is larger than one person and the institution is seeking a leader who reflects that mindset. Pharmacy programs could be transparent with the recruitment process and set the expectation that administrative positions are intended to be temporary.

\section{Arguments Opposing Term Limits}

Term limits are a solution without a clear problem. The issues that are ostensibly addressed by term limits have significantly more complexity and nuance than a simple "one-size-fits-all" solution would cover. Stable and continuous leadership, time for leadership development, evaluation of effective leadership, and avoiding management burnout will result in academic administrators who are engaged and trusted. Limiting a faculty member's time in leadership does not create these virtues.

Term limits may function as a temporary solution to resolve the issue of unproductive administrators or provide a means to ensure predictable change within an organization; however, it comes with significant costs. Term limits can contribute to lack of stability and continuity within a school or college, and they impact the administrator's leadership in the organization. It can take approximately six to 18 months for a person to fit into a new role in an organization. ${ }^{21}$ For example, a department chair who is hired externally will need time to get to know the faculty members, develop mutual trust and respect, create a shared vision with the department, and mentor faculty members towards progress and success in their careers. Even a new department chair who was an internal candidate may face similar challenges related to adjusting to the new role and increased responsibilities. If term limits are in the range of three to five years, a significant portion of the available time may be consumed with establishing trust and working relationships with the faculty members and other stakeholders. At the end of the term, the process would have to start over with a new department chair. In the role of dean, time is also needed to develop and foster community relationships in order to continue to foster the growth of the program. Additionally, pressures from both within and outside of the pharmacy program may hinder a dean's ability to function at optimal efficiency in achieving strategic goals. The "ticking clock" of a term limit would put artificial strictures on a leader's ability to fully implement his or her vision for the organization.

Faculty members tend to thrive when they have stability and less disruption from the change of leadership, particularly at the department chair level. ${ }^{5}$ Stability is needed for relationships to be developed and nurtured and for trust building. Faculty members should be allowed to focus on their goals rather than being artificially forced to work with a new administrator. Having the same individual mentor faculty members through a six- or seven-year promotion and tenure period, for example, would be preferable to faculty members having to adjust to and develop a mentor-mentee relationship with two or even three chairs who may have very different styles and expectations.

Term limits could also result in a loss of institutional memory, which is built through continuity, and institutional expertise, which in turn is built from repeated problem-solving and learning from experiences. This loss of institutional memory could have an impact on the longterm strategic goals and associated outcomes. For example, a chair who does not need to worry about duration of appointment can set a strategic plan in motion, implement it, and take ownership of it. Alternatively, limited time in a role may allow an administrator to postpone uncomfortable or inconvenient tasks (especially if the tasks come up at the end of the term) and leave his or her successor to deal with those issues. This, in turn, may lead to issues with morale among faculty members. The administrator may have been proficient in the position early on but is now limited in his or her perceived authority because other faculty members may be waiting for the next person to take over and make unknown and potentially substantial changes. 


\section{American Journal of Pharmaceutical Education 2020; 84 (1) Article 7462.}

Term limits can also arbitrarily cut short any on-thejob growth and development that can occur and limit the ability of the leader to develop expertise and reach their potential. Beyond the time needed for on-the-job training, the transition from faculty member or even mid-level leadership to dean can be extremely challenging, even for those "prepared" by leadership development programs or other systematic training methods. ${ }^{22}$ In his 2000 paper, Gmelch noted that on the faculty side of academia, seven or more years of service are required to attain the rank and status of tenure and associate professor, while an additional seven or more years are required to achieve the distinction and recognition of full professor. ${ }^{22}$ Most leadership development programs, however, occur over a weekend or a year at most, which is comparably an insufficient amount of time to develop leadership skills. Psychology researcher Anders Ericsson has noted in his extensive research that a minimum of 10 years of deliberate practice is needed in any field, sport, or discipline to develop expertise. ${ }^{23}$

All administrators, just like faculty members, require periodic evaluation to facilitate growth and improvement. These evaluations should be based upon overall effectiveness rather than simply at a pre-specified time period Periodic evaluation can help to ensure accountability and help administrators learn about their shortcomings for future improvement. Structured annual reviews coupled with a major review after a set period of time (ie, three to five years) could be used. In each setting, clear goals need to be established. A "360 degree" or other comprehensive review process should be conducted so that all of the stakeholders can provide input. ${ }^{24}$ It is critical that these reviews include both summative and formative components to allow opportunity for the administrators to improve and correct any deficiencies (formative) while retaining an aspect of accountability (summative). The periodic review needs to identify strengths and weaknesses and set targets for the subsequent review. If problems are not solved or targets not met, this could serve as the basis to remove the administrator. As noted, administrators generally serve at the pleasure of the dean or provost and can be replaced in the event an administrator does not satisfactorily respond to a comprehensive review.

There may be a perception that administrators without term limits become complacent and are less "action-oriented." If this issue exists within an organization, its source is likely multifactorial and would not be solved simply by instituting arbitrary term limits on administrative positions. Burnout and complacency are major contributors to loss of motivation for leaders. ${ }^{25,26}$

Administrators are not the only ones who can experience burnout; faculty members can fall into this trap as well. ${ }^{27}$ Burnout, according to a survey by Kronos, a human resources firm, results from unfair compensation, unreasonable workloads, and/or poor management. ${ }^{28,29}$ These three issues cannot likely be resolved or ameliorated without support from upper management. Additionally, providing sufficient resources, both financial and human, is crucial for avoiding faculty burnout. If these resources are not available to administrators, term limits may become the de facto policy because of high turnover rather than because it is the preferred leadership approach in an organization.

As administrators mature in their positions, they may become complacent, characterized by the sense that he or she is safe and secure in the position, possibly leading to decreased productivity. Complacency, like burnout, can be prevented but requires a proactive approach. ${ }^{30}$ One of the reasons the "sabbatical" was created for faculty members was to rejuvenate them and restore their excitement about their jobs. Implementation of a scheme whereby administrators could go on sabbatical could be effective at restoring an administrator's action level. A variety of local solutions have been used, including walking meetings, mental health days (with the support of superiors), encouraged utilization of vacation time, "work-at-home" days, and promotion of work-life balance or blend. Implementation of these approaches is a proactive approach to the problem of burnout; however, it does require significant buy-in from the administrative team but will likely benefit all administrators, regardless of their length of service. Also, while these local solutions may be functional or effective within an individual organization, they do not address larger issues of compensation, workload, or poor management that could be present. Additionally, there may be a lack of interest among faculty for assuming additional leadership responsibilities.

\section{CONCLUSION}

The debate over term limits for administrative appointments in pharmacy programs highlights critical issues that all organizations must face, including leadership effectiveness, succession planning, mentorship, turnover, and burnout. Arguments in favor of term limits include encouraging succession planning, contributing to increased gender diversity, and cultivating continuous improvement. Arguments in favor of no term limits include stable and continuous leadership, time for leadership development, and allowing for appropriate evaluation of leadership effectiveness. More focused and systematic research is needed to determine the extent of pharmacy programs possessing term-limited administrative positions and how those term limits are structured. Additionally, research is needed to show how term limits within academic pharmacy affect faculty and administrator productivity and satisfaction, as 


\section{American Journal of Pharmaceutical Education 2020; 84 (1) Article 7462.}

well as how any changes to term limit policies impact overall organizational goals.

\section{REFERENCES}

1. Dunn DS, Halonen JS. Have you stayed too long? Chron High

Educ. July 25, 2017. Accessed January 31, 2020.

2. Carey JM, Niemi RG, Powell LW, Moncrief GF. The effects of term limits on state legislatures: a new survey of the 50 states. Legis Stud Quar. 2006;31(1):105-134.

3. Kousser T. Term Limits and the Dismantling of State Legislative Professionalism. Boston, MA: Cambridge Press; 2005.

4. Smith AB, Stewart GA. A statewide survey of new department chairs: their experiences and needs in learning their roles. New Dir Comm Coll. 1999;1999(105):25-36.

5. Gmelch W. The call for leadership: why chairs serve, what they do, and how long they should serve. AKA Monographs: Leading and Managing the Kinesiology Department. 2015;1(1):1-12.

6. Council of Independent Colleges. Spring Survey of Department and Division Chairs Shows Diversity in Appointment and Compensation Practices. https:/www.cic.edu/news-information/ independent-newsletter/summer-2016/department-chair-survey. Published Summer 2016. Accessed January 31, 2020.

7. University of Memphis. College of Arts and Sciences. Length of Term and Transition to a New Chair. https://www.memphis.edu/cas/ cas_chair_handbook/chair-term-compensation.php. Updated August 2019. Accessed January 31, 2020.

8. Cipriano RE, Riccardi RL. A chair: the linchpin of the university. Department Chair. 2012;23(1):13-15.

9. Accreditation Council for Pharmacy Education. Accreditation Standards and Key Elements for the Professional Program in Pharmacy Leading to the Doctor of Pharmacy Degree ("Standards 2016"). https://www.acpe-accredit.org/pdf/Standards2016FINAL.pdf. Accessed January 31, 2020.

10. Assemi M, Yu J, Liu S, Corelli RL, Hudmon KS. Educational attainment and academic profile of deans and chairs at US pharmacy schools. Am J Pharm Educ. 2017;81(7):Article 5928.

11. Boyle CJ, Chesnut R, Hogue MD, Zgarrick DP. The influence of interim deans: more than keeping the ship afloat and warming the captain's seat. Am J Pharm Educ. 2016;80(7):Article 112.

12. Todnem R. Organizational change management: a critical review. J Change Manag. 2005;5(4):369-380.

13. Harrell E. Succession planning: what the research says. Harvard Bus Rev. https://hbr.org/2016/12/succession-planning-what-theresearch-says. Published December 2016. Accessed January 31, 2020 .

14. Conklin MH, Desselle SP. Job turnover intentions among pharmacy faculty. Am J Pharm Educ. 2007;71(4):Article 62. 15. American Association of Colleges of Pharmacy. 2016-2017 Profile of Pharmacy Students. https://www.aacp.org/sites/default/ files/2018-05/fall-2017-profile \%20of\%20pharmacy $\% 20$ studentsdegrees\%20conferred.pdf. Accessed January 31, 2020.

16. American Association of Colleges of Pharmacy. 2017-18 Profile of Pharmacy Faculty. https://www.aacp.org/system/files/PPF_1718final.pdf. Accessed January 31, 2020.

17. Draugalis JR, Plaza CM, Taylor DA, Meyer SM. The status of women in US academic pharmacy. Am J Pharm Educ. 2014;78(10):Article 178.

18. Carter O, Nathisuwan S, Stoddard GJ, Munger MA. Faculty turnover within academic pharmacy departments. Ann

Pharmacother. 2003;37(2):197-201.

19. Rayburn W, Grigsby K, Brubaker L. The strategic value of succession planning for department chairs. Acad Med. 2016; 91(4):465-468.

20. Collins J. Level. 5 leadership: the triumph of humility and resolve. Harvard Bus Rev. https://hbr.org/2005/07/level-5leadership-the-triumph-of-humility-and-fierce-resolve. Published July-August 2005. Accessed January 31, 2020.

21. Byford M, Watkins MD, Triantogiannis L. Onboarding isn't enough. Harvard Bus Rev. https://hbr.org/2017/05/onboarding-isntenough. May-June 2017. Accessed January 31, 2020.

22. Gmelch WH. Leadership succession: how new deans take charge and learn the job. J Leadership Stud. 2000;7(3):68-87.

23. Ericsson KA, Krampe RT, Tesch-Romer C. The role of deliberate practice in the acquisition of expert performance. Psychol Rev. 1993;100(3):363-406.

24. Qualtrics. 360-degree Employee Assessments. https:// www.qualtrics.com/qualtrics-360/360-degree-employeeassessments. Updated 2018. Accessed January 31, 2020. 25. Llopis G. The dangers of complacent leadership. Forbes. https:// www.forbes.com/sites/glennllopis/2014/08/05/the-dangers-ofcomplacent-leadership. December 5, 2014. Accessed January 31, 2020.

26. Knight R. How to overcome burnout and stay motivated. Harvard Bus Rev. https://hbr.org/2015/04/how-to-overcomeburnout-and-stay-motivated. April 2, 2015. Accessed January 31, 2020.

27. Papathanasiou IV, Fradelos EC, Kleisiaris CF, et al. Motivation, leadership, empowerment and confidence: their relation with nurses' burnout. Mater Sociomed. 2014;26(6):405-410.

28. Kronos, Inc. The employee burnout crisis. https://

www.kronos.com/resources/employee-burnout-crisis. Published 2017. Accessed January 31, 2020.

29. Kronos, Inc. Moving beyond burnout: strategies to sustain engagement and retain workers. https:/www.kronos.com/resources/ moving-beyond-burnout-strategies-sustain-engagement-and-retainworkers. June 2016. Accessed January 31, 2020.

30. Spritzer AD. It's not easy being dean. BizEd (blog). https:// bized.aacsb.edu/articles/2004/november/its-not-easy-being-dean. November 1, 2004. Accessed January 31, 2020. 